\title{
Organ Transplantation and the Commercialization of Human Biological Material: Some Philosophical and Jurisprudential Implications
}

\author{
George Mousourakis* \\ Department of International Relations, Ritsumeikan University, Japan
}

\begin{abstract}
The advances in molecular biology, medicine and the neurosciences and the rapid development of genetic technology in recent years have given rise to a host of questions about the way in which the medical scientific community and biotechnology industry treat persons and their bodies. What is described as the 'commodification' of the human body, the notion that a person's body is a collection of parts that are separable and commercially transferable, is said to pose a major challenge to traditional intuitions and cherished beliefs about personhood, the sanctity of human life and the foundations of its moral dignity. As the commodification of the body is today becoming increasingly prominent it is necessary to consider whether it is appropriate to see the human through the conceptual lens of property and examine and ponder what radical changes may be introduced to our sense of self-identity if this paradigm is uncritically embraced. The aim of this paper is to identify and comment on important philosophical and ethic-legal perspectives that have furnished the framework within which questions concerning personhood and the use of human body and its parts are raised and sought to be answered.
\end{abstract}

\section{CONCEPTIONS OF THE HUMAN BODY IN WESTERN MEDICINE}

There is a fundamental difficulty with the way the human body is perceived in Western society. Our understanding of the body is said to be characterized by the tension between 'the mundane and the sacred'- between the view of the body as an object and a material thing and its conception as the (sacred) site of personhood. This tension occupies a central place in contemporary [1] debates concerning the scientific and medical use of human bodies and body parts. Some commentators describe this as the 'paradox' of the body, a situation that has its roots in the Cartesian dualism of body and mind, with the body being regarded as a passive container or shell of the active mind. In today's technological culture, the body is said to be the inescapable other of human personal existence, the weak and dominated partner of the mind [2].

An examination of the history of Western medicine can provide useful insights on how this notion of the body evolved. As scholars have observed [3], in the later medieval age in Europe there were several competing perceptions of the body and illness. The dominant notion drew upon the religious conception of illness as being the responsibility of the person who has brought the condition upon themselves through a sinful lifestyle. At the same time, naturalistic understandings invoked earlier Greek and Roman traditions. The Graeco-Roman approach to illness had two aspects: the 'Asclepian' and the 'Hygeian', the former using herbs and surgery to restore

\begin{tabular}{c|l} 
Quick Response Code: & $\begin{array}{l}\text { Address for correspondence: George Mousourakis, Department of International } \\
\text { Relations, Ritsumeikan University, Japan }\end{array}$ \\
\cline { 2 - 4 } & $\begin{array}{l}\text { Received: November 21, } 2019 \text { Published: January 06, 2020 } \\
\text { How to cite this article: George Mousourakis. Organ Transplantation and the } \\
\text { Commercialization of Human Biological Material: Some Philosophical and Jurisprudential } \\
\text { Implications. 2020 - 2(1) OAJBS.ID.000131. DOI: 10.38125/OAJBS.000131 }\end{array}$ \\
\hline
\end{tabular}


the body to health, the latter emphasizing external factors, such as lifestyle and the environment [4]. In Roman times, the Asclepian perspective began to overshadow the Hygeian one. As cure came to be more important than care, a growing importance was placed on health as being connected with what happened inside the body. The emergence of Cartesian dualism and the growth of the science of anatomy in the fifteenth and sixteenth centuries precipitated the shift from the Hygeian to the Asclepian understanding of illness and the transformation of the body from a source of knowledge of both body and soul to an object of a mechanical science. The notion that the body was a conglomeration of different parts eventually resulted in its separation from the mind. The body became the realm of doctors and biologists, the mind the concern of religion and philosophy. The understanding of the human body as a kind of machine, which, when appearing to function abnormally needed to be investigated and, if possible, fixed, laid the foundation for the development of modern medicine and medical science in the nineteenth century.

\section{CARTESIAN DUALISM}

As already noted, the development of modern Western medical science was strongly influenced by Cartesian dualism. According to Descartes (1596-1650), there are two distinct notions: the body and the mind (also referred to as thinking substance or soul) [5]. The body, as a body, is just a machine with its own internal economy and sources of energy [6] and, as Descartes remarked, 'it is not that the body dies because the soul leaves it, but that the soul leaves it because the body has died'. While the body is alive, however, a soul is joined to it in such a way that some of the movements of the body are produced by the soul, and some experiences of the soul are produced by changes in the body [7]. Descartes believed that the problem of the relationship between soul and body arose only in the case of human beings. In the case of animals, he seems to have thought that all their movements were produced by purely mechanical causes in a system of stimulus and response, and that they were accordingly merely machines, having in the proper sense no souls [8]. The problem of the union of soul and body is central to Descartes' metaphysics. In his view, which represents the classical expression of dualism, there are in the realm of created beings two and only two fundamentally different kinds of substances or existing things: 'thinking' (mind, soul or consciousness), which is unexpended and indivisible, and matter, which is extended and divisible. It follows that our physical bodies, including our brains, being part of the extended divisible world of matter, can have no part in our essence as thinking beings. This dualistic perspective was the heart of Descartes' attempt to reconcile the Catholic faith and the advantages of seventeenth century science. Although there was some causal interaction between souls and bodies, he thought that he had sufficiently isolated souls from matter, which alone was subject to the mechanical laws which science was developing. Natural science, Descartes believed, could ultimately complete a deductive theory of all mechanical changes in the material world, and so of all physical events; these would include all movements of human bodies which were not the product of free-will, but freewill and the soul itself would remain essentially outside the reach of scientific laws.

By conceiving of the person as separable into body and mind and stressing the primacy of the mind over the body, dualism helped demystify the body making it a morally neutral secular object [9]. Scientists gained the freedom to inquire into the functioning of the body and this precipitated the development of modern medical science. At the same time, however, the separation of body and mind and the mechanistic conception of physical processes made possible also the objectification of the human body, as they imply that the body and its parts may be treated like other possessions.

\section{THE MATERIALIST CONCEPTION OF THE PERSON}

Materialism, in its philosophical sense, is the view that all that exists is material in nature or is wholly dependent upon matter for its existence. This view comprises: (a) the general metaphysical thesis that there is only one fundamental kind of reality and that this is material; and, (b) the more specific thesis that human beings and other leaving creatures are not dual beings composed of a material body and an immaterial soul, but are fundamentally material in nature.

Forms of materialism appear in the history of Western thought as far back at least as Democritus (c. 460-c. 370 BC) and Epicurus (341-270 BC), who attempted to describe natural processes and human experience in terms of arrangements and rearrangements of changeless atoms, or indivisible material particles, in empty space. The things, animals and people of the natural world are formed by the coalescence of these particles and decay as they disintegrate and form new and different combinations. On this view, thought is a form of sensation and sensation is explained in physical terms as the changes brought about in the atoms composing the soul by atoms emitted from objects outside the body and received through the sense organs. When the body decays or is destroyed, sensation is no longer possible and the soul itself disintegrates into its ultimate atoms. In this respect, the distinction between soul and body is not a distinction between the immaterial and the material, but between different kinds of material wholes.

With the development of the physical sciences in the seventeenth and subsequent centuries speculative atomism was adopted as an explanatory principle of physics and chemistry and thus gave rise to scientific materialism. This perspective drew support from the theory of organic evolution, which proposed that life and mind had evolved from inanimate matter. Advances in physiology reinforced this view, since it was claimed that the existence and scope of mental life depended upon the size and configuration of the brain. In the twentieth century there have been two-man forms of materialism: dialectical materialism and physicalism. Dialectical materialism (associated with Marxist thinking) sees matter not as something static on which change and development have to be imposed ab extra, but as containing within its own nature those tensions (or contradictions) which provide the motive force for change - a vision which, it is claimed, is lacking in earlier 'mechanistic materialism'. Physicalism rests on the view that all propositions asserting 'matters of fact and real existence' can be formulated as statements about publicly observable physical objects and activities [10]. From this point of view, it has been argued that the only meaningful statements about minds must refer to bodily behavior of some sort, since there can be no genuine public verification of a statement purporting to state the private experiences of one individual. It is important to notice that materialists do not deny the existence of mind or consciousness; what they deny is that mind or consciousness are characteristics of immaterial souls.

As materialism views the person as a wholly material being and the mind as a physical manifestation of the body, it appears less likely to lead to 'objectification'. However, a strongly reductionist materialist approach (evident in popular views of human genetics) 
[11], can result in the body being 'objectified' and in people treating their body parts as commercially transferable objects.

\section{AUTONOMY AND THE FREEDOM TO CHOOSE}

Autonomy [12] refers to the capacity of and the right to selfdetermination - the ability of formulating and following a life plan of one's own choosing. Respect for autonomy derives from two fundamental principles associated with two distinct traditions in moral philosophy. The first is Immanuel Kant's principle of respect for persons as autonomous ends-in-themselves. Persons are autonomous in the sense that they have the capacity for reason and can apply the moral law to themselves. According to Kant, there is one fundamental principle of morality, the 'categorical imperative'. This principle is based on reason alone, especially on the idea that human beings are defined essentially in terms of the capacity for reason. The categorical imperative consists of two formulations: (a) act only on that maxim by which you can at the same time will that it should become a universal law; and, (b) act so that you treat humanity, whether in your own person or in that of any other, always as an end and never as a means only. This imperative is 'categorical' in the sense that it is unconditional and therefore allows no exceptions. It applies to all humans regardless of personal desires, plans or interests.

Kant's principle lies at the heart of the deontological tradition Deontology defines the rightness or wrongness of an action in terms of a duty or obligation to respect the rights and values of persons. It specifies constraints on what we can or cannot do to others, constraints that can prohibit actions that bring about good consequences. Thus, from a political perspective, Kant's ethical theory is conceptually congruent with liberal rightsbased political theories, which favor institutional arrangements which give priority to individual liberty over collective welfare. A modified version of deontology, known as non-consequentialism, says that consequences can matter, but they are not the main motivation for action. The focus remains on rights, duties and the person as an end-in-itself. The deontological requirement that the individual's capacity to make autonomous and rational choices should be respected carries with it the normative implication that collective and societal interests should be morally subordinate to the individual's exercise of his free and autonomous choices as reflective of human dignity. Kant connected human dignity with the faculty of reason and emphasized the duty to take care of one's own body. He specifically argued against trade in body parts, stating the person inhabits the body and cannot leave it, and therefore respect for the person must involve treating the body as an end and not as a means [13].

The second principle is John Stuart Mill's principle of liberty, which says that a person is sovereign over his or her own body and mind. This principle lies at the core of the liberal tradition. In his work On Liberty (1859) Mill related three basic freedoms of the individual, those of belief, of tastes and pursuits and of uniting with others, to the powers of authority and social demands. Men must be encouraged to express their individuality. Actions, however, have consequences and it is the duty of those who govern and society to restrain men from damaging others' interests and to require them to assume responsibility in furthering the interests of their community. Nevertheless, Mill argued that restrictions on the liberty of the individual are justifiable only in so far as they are necessary to prevent actual harm to others. We are not entitled to use social power to impose a set of moral standards where breach of these standards causes no injury to another nor should we use our collective might to dictate a person's behaviour because it is felt that it is not in someone's best interests to act in a particular manner. The 'harm principle' rests on the idea of autonomous choices and this presupposes the capacity for rational decisionmaking and action. A distinction may be drawn between being a rational decision-maker and being a rational agent, or between 'decisional' and 'executional' autonomy. A person is autonomous in the former sense if he or she can make personal, informed choices; and he or she is executionally autonomous insofar as he or she is able to implement those choices.

The primacy of autonomy in Western thought has meant that individuals tend to be perceived as autonomous, private persons with strong controlling interests in their bodies. Whilst strong views about the value of autonomy do not necessarily lead to objectification, one of the most commonly used arguments in support of establishing a commercial trade in body organs revolves around the liberal notion that autonomous individuals should be able to do as they please with their bodies. This argument hinges upon two often unsubstantiated assumptions: (a) that the human body and body parts can justifiably be objectified; and (b) that organs can be treated as property, notwithstanding concerns about exploitation [14]. It is submitted that in combination with dualistic or materialistic perceptions of the person, a narrowly defined conception of autonomy tends to reinforce the view that the human body can be objectified and commodified.

\section{THE COMMODIFICATION OF THE HUMAN BODY: ETHICO-LEGAL IMPLICATIONS}

The philosophical perspectives outlined in the previous paragraphs furnished an important part of the framework within which current conceptions of the body and its relationship to personhood evolved. What remains to be addressed is the normative question: "what is wrong with the objectification and commodification of the human body?" Many authors employ the concept of commodification without explaining its theoretical basis. Nevertheless, there is one point about which there is very little doubt: the concept is negatively charged. In the conceptual history of the West commodities acquired traits understood almost as the counter-image of emerging ideas about personhood: they were non-human, passive and, as such, in no need of respect. They were perceived as the natural means to the human person as an end - in other words, as objects satisfying human needs. As commentators have pointed out, if the body were to be redefined as tradeable property, it would be transformed into something of a lower moral standing [15]. Radin argues that to determine the significance of a person's relationship with an object one needs to consider the type and level of pain suffered by the loss of the object. If the object is loosely held (e.g. one's bicycle), then it can be easily exchanged or replaced. On the other hand, if a person's relationship to the object is close and personal (e.g. a family heirloom), the loss of the object cannot be alleviated by its replacement. This leads to a hierarchy of entitlements, so that the closer the connection of an object to personhood, the stronger the entitlement. From this viewpoint, Radin asserts that some items, such as bodily organs, cannot be regarded as property at all [16]. To treat organs as fully alienable would, in the words of Bourianoff Bray, "encourage a perception of body parts as interchangeable commodities and undermine the recognition of the human body as the physical embodiment of the personality" [17]. According to Wilkinson, commodification involves an attitude to human beings and body parts which (a) denies their subjectivity, (b) prescribes instrumentality and (c) facilitates 
exchangeability [18]. The examples used by commentators often highlight the monetary dimensions of organ transfers and draw attention to the alienation of body parts as an infringement of personal integrity [19]. Some scholars have added a political dimension to the infringement of personality by emphasizing the exploitative character of such alienation [20]. In general, anticommodification scholars suggest that if we introduced financial considerations to the body, we would transgress long-established ethical norms. As Radin has pointed out, "the characteristic rhetoric of economic analysis is morally wrong when it is put forward as the sole discourse of human life" [21]. The close connection between the human body and personhood means that bodies cannot be regarded as a commodity. Indeed, a common tenet in contemporary biotechnology jurisprudence clearly exempts the body from being treated as tangible property [22].

However, the main difficulty with this approach is that body parts are today used for a variety of purposes without this to be always involving a violation of human dignity. Every year millions of people around the world undergo surgeries involving soft-tissues, skin, bones and tendons acquired from living donors or cadavers. Human tissue and organs suitable for burial at death or disposed of after medical procedures are given new life and value in research laboratories, biotechnology supply companies and human beings. Market realities in the body already exist [23] and our failure to take account of this entails its own set of adverse consequences. These include an inadequate nomenclature, an increased risk of exploitation [24] and continued abuse of human subjects, and a loosely monitored and unregulated but robust market in buying and selling human body parts. The rapid development of biotechnology has increased demand and uses for human body parts, especially tissues and cells. Human samples are not only an indispensable part of the biomedical research process, but they are now used in the production of many commercial products ranging from drugs and vaccines to pregnancy test kits. Body parts now used for biotechnological purposes were in the past deemed human waste and thus disposed of by medical practitioners and institutions. Moreover, today there is a growing market in body parts as doctors, hospitals and patients have come to rely on their availability. In light of these realities one might say that body parts could be regarded as 'special commodities' pertaining to a special sphere of social exchange. Provided that certain rules are observed, it is possible to establish room for exchange of body products. Of importance, in this respect, is the question of how human body parts are acquired. A host of problems stems from the fact that acquisition sometimes occurs through such means as compulsion, fraud [25] or misappropriation from funeral homes and crematoriums, medical practitioners and researchers.

Nevertheless, a few scholars maintain that to place a monetary value on the body is unjustified, for it diminishes personhood and undermines our otherwise homogenous understanding of its social, moral and legal status. To these scholars, the human body is a sacred entity and its status as such is threatened by any associations with financial assessments and market terms and conditions [26]. With respect to DNA, it is argued that a person's genetic code is a unique identifier of the individual and, as such, is fundamentally private. (Of course, a person's physical and psychological characteristics are not fully determined by their DNA - it is in conjunction with environmental and socio-cultural factors that DNA makes a person unique.) It is submitted that treating DNA as little different from the blood or tissue in which it is contained and thus as equally commodifiable tends to devalue personhood. An extrapolation of this approach is that the body should remain an inalienable vessel, irrespective of the uses public authorities and private entities find for it. Anti-commodification commentators often invoke the scourge of human slavery in the past and present to buttress their arguments and to demonstrate in stark terms the possibly grave consequences of placing monetary value on human beings [27]. It is pointed out that the widespread acceptance of a reductionist view of the person, in conjunction with an increased emphasis on personal autonomy and the freedom to choose, can lead to a situation where individuals no longer care about their personhood or physical integrity. At a societal level, this might precipitate the development of a huge market for body parts and genetic material that can readily lead to exploitation of poor and disenfranchised individuals and communities. Anti-market bioethicists warn that the poor and destitute may be drawn to markets and when this happens sellers may engage in socially undesirable forms of conduct, such as stealing body parts. According to these scholars, commodification of the body is akin to slavery - a paradigm to be avoided.

Radical legal theorists often argue that deliberation on the human body in market terms reinforces the subordinate status of disadvantaged groups in society and vertical power relationships [28]. Anti-market conservatives equally reject monetary valuations placed on human biological resources, but for different reasons. Their concerns are sometimes grounded in the abortion debate, religious doctrine and moral consideration [29]. There are some scholars in other schools of thought who may equally deny the notion of property in the body, such as the legal formalists, whose devoted adherence to judicial or legislative precedent entails an inflexibility to the introduction of exogenous values in the law [30].

Although the anti-commodification arguments enjoy a broad intuitive appeal, they tend to ignore the evolving nuances of body parts with respect to law and biotechnology. Ultimately, the fear to speculate and even contemplate the body in any legal terms other than our late nineteenth century understanding limits the potential for robust, informed, meaningful contemporary dialogue and debate on a critical contemporary issue. This fear tends to undercut scholars' ability to credibly engage in policy debates concerning the reach and normative positioning of biotechnology within the legal sphere and can lead to the avoidance of substantive inquiry and analysis of market realities that already exist. It is thus unsurprising that biotechnology outpaces legal response, including the development of regulation and a comprehensive and meaningful policy that would be attentive to social, ethical and cultural issues, and courts seem unprepared to handle the relevant cases. Meaningful public policy about the use and value of stem cells, organ transplantation, cloning etc. cannot and should not be developed in a vacuum. When commodification is described as posing a moral problem, the proposed solution appears to be a world in which the use and exchange of products derived from human bodies involve no monetary aspects. This is a most unlikely scenario, and one that would probably give rise to a few other social and moral concerns in terms of denied access to treatment. I am not here saying that anti-commodification theorists are wrong, but that there is a need for scholars, including legal experts, to engage in more detail with the intricacies of the exchange systems that are established and to explore which are the organizational, political and proprietary structures that can warrant the entitlements of those in need. To restrict ourselves to the ways in which the objectification/commodification of the body is already occurring and thus limit our critique to moral denunciation of inevitable 
practices seems to me a greater danger than engaging in scrutiny of their implications.

Entrenched legal formalism in a rapidly expanding biotechnological age tends to hinder meaningful development of the law concerning the ownership, dispensation and remedies involving body products. Formalistic rule making (or the lack thereof) does not go far enough in recognizing and responding to the shifting of culture, society and biotechnology. It is important that the law evolves to address the issues that the development of biotechnology entails. More specifically, legislative and judicial neglect of the processes by means of which biotechnology interferes with individual liberties can pose many serious problems. For instance, consent legislation designed to protect individual autonomy and promote safety may be rendered ineffectual through surreptitious tissue harvesting often from unsafe individuals (e.g. victims of natural disasters or violent crimes). This increases the likelihood that unhealthy body tissues will enter the marketplace and harm those whom the relevant legislation is designed to safeguar [31]. To prevent this, secondary or supporting measures need to be taken to give full meaning to a potential donor's (or his/ her relatives') choice to accept or refuse extraction. As regards judicial decision-making in biotechnology cases, it is observed that judges tend to remain attached to the position that it is not their role to alter the law to respond to new problems brought about by biotechnology. Instead, they operate on the assumption that it is the legislature's role to make the necessary changes to the law [32]. The judges' hesitance to tamper with entrenched notions of the body by introducing new meaning to the law, recognizing alternative paradigms and solutions, constitutes an obstacle to legal development. As a result, the law relating to body parts, instead of being a robust representation of nuanced thinking on an extremely complex issue, appears feeble and incomplete. In the biotechnology era it is important that judges take a leading role in bringing the law up to date, especially through clarification of the body's legal status.

\section{CONCLUDING REMARKS}

In an expansive biotechnology age moral discourse is faced with the formidable task of securing and reformulating the fundamental intuitions about human worth and the moral status of persons within a new framework of thought that can neither completely ignore nor fully endorse the assumptions and beliefs of the cultural tradition within which the concept of personhood originated. These calls, among other things, for conceptual clarification and careful analysis of the relationship between personhood and the human body and its different usages in moral discourse before its normative and legal implications can be explored. Anti-commodification scholars are right to suggest that by introducing financial considerations to the body we transgress, to some extent, traditional ethical norms and settled legal doctrine. However, a logic of exchange, involving the distribution of body parts inside a system based on donation, informed consent and extended rights of disposal by individual donors, does not exclude the commodification of certain body parts within a clearly defined normative-legal framework. Notwithstanding our aversion to discussing the human body in market-like terms, market realities in the body already exist and our failure to recognize this has its own set of adverse consequences. In particular, a failure on the part of the legal system to be proactive in light of privatized biotechnology and its drive for body parts can produce nefarious systems that may result in unequal treatment, exploitation of the vulnerable, and lack of resources for the aggrieved.

\section{REFERENCES}

1. Shilling C (1993) The body and social theory. Sage, UK, 26.

2. Longhurst R (1995) The body and geography. Gender, Place and Culture 2(1): 97-106.

3. Bell D, Valentine G (1995) Mapping desire: Geographies of sexualities, Routledge, London, Pile S (1996) The body and the city. Routledge, London.

4. Moon G (1995) Health Care and Society in Moon G and Gillespie R. (eds), Society and Health, (London Routledge), $51 \mathrm{ff}$.

5. In ancient Greece doctors worked under the patronage of Asklepios, the god of medicine, while healers served Asklepios' daughter Hygeia, goddess of health. The worshippers of Hygeia viewed health as the natural order of things, a positive attribute to which men are entitled if they live their lives wisely and well. For them the most important function of medicine is to bring to light and teach the laws of mature which will ensure a man a healthy mind in a healthy body. On the other hand, the followers of Asklepios believed that the principal role of the physician is to cure disease, to restore health by correcting any bodily defects caused by accidents of birth or life.

6. This kind of dualism is sometimes referred to as 'attributive' because it claims that there are two kinds of attributes and thus that all substances are of just two ultimate kinds. Dualism is distinguished from monism, the philosophical theory that maintains that minds and bodies do not differ in their intrinsic nature; the difference between them lies in the way in which a common 'neutral' material is arranged.

7. Descartes describes the human body as a machine, albeit a machine created by God, incomparably better ordered, and [which] has in it more admirable movements than any of those which can be invented by men. Discourse on Method (London Dent 1994) (originally published in 1637), 42.

8. In his work Passions of the Soul Descartes proposes that there is in the body a physical place of this interaction, and that this is the pineal gland at the base of the brain. This gland, he hypothesized, could be moved directly by the soul and thus agitate the 'animal spirits' which, in common with many seventeenth century theorists, he believed to flow and to transmit movements to all parts of the body. In the opposite direction, changes in the animal spirits induced by stimuli to the body could move the gland and thus affect the soul.

9. However, Descartes is not always consistent on this point, and this raises important questions about his conception of consciousness.

10. Lysaught MT (1995) Body: Social theories. In Reich TW (ed.), Encyclopedia of bioethics. Simon \& Schuster Macmillan, New York, USA, 1: 300-305.

11. This doctrine was formulated by some members of the Logical Positivist movement and was later adopted by some leading representatives of the identity theory of mind.

12. Nelkin D, Lindee MS (1995) The 'blueprint' metaphor for the human genome (the hereditary information encoded in the human DNA) has come to dominate public perception, and a growing number of people seem to believe that all forms of behaviour can be explained by reference to genetic causes. The DNA mystique: The gene as a cultural icon. New York, USA.

13. From the Greek words, auto: self and nomos: law.

14. Kant I (1997) Lectures on ethics, heath P, Schneewind JB (Eds.), Heath P (trans), Cambridge UP 144-151.

15. Kevorkian J (1992) A controlled auction market is a practical solution to the shortage of transplantable organs. Medicine and Law 11(1-2): 47 55. Radcliffe-Richards J, Daar AS, Guttmann RD, Hoffenberg R, Kennedy I, et al. (1998) The case for allowing kidney sales. Lancet 352: 1950-1952.

16. According to Holland, commodification contributes to a diminishing sense of human personhood. Holland S (2001) Contested commodities at both ends of life: Buying and selling gametes, embryos, and body tissues. Kennedy Institute of Ethics Journal 11: 263. 
17. Radin MJ (1982) Property and personhood. Stanford Law Review 34 957. (1987) Market-Inalienability. Harvard Law Review 100: 1849.

18. Bourianoff BM (1990) Personalizing personalities: Toward a property right in human bodies. Texas Law Review 69: 209-244, at 241.

19. Wilkinson S (2000) Commodification arguments for the legal prohibition of organ sale. Health Care Analysis 8: 189-201.

20. Sharp LA (2007) Bodies, commodities, and biotechnologies: Death, mourning, and scientific desire in the realm of human organ transfer. New York.

21. Scheper HN (2000) The global traffic in human organs. Current Anthropology 41: 191-224. (2001) Commodity fetishism in organ trafficking. Body \& Society 7: 31-62.

22. (1987) Market-Inalienability. Harvard Law Review 100: 1851.

23. Knowles LP (1999) Property, progeny and patents. Hastings Center Report 29: 38 \& Fox M (2000) Pre-persons, commodities or cyborgs: The legal construction and representation of the embryo. Health Care Analysis 8: 171.

24. Baum K (2001) Medical researchers partake in the market of human body parts when they are granted authorization for medical tests that later result in patenting of cell lines or other similar financially beneficial medical products. Furthermore, a rather vigorous market in human eggs exists and is well-publicized and documented. Golden eggs: Towards the rational regulation of oocyte donation. Brigham Young University Law, USA, Review 107-66.
25. Dickenson D (2004) Consent, commodification and benefit-sharing in genetic research. Developing World Bioethics 4(2): 109.

26. When tissues donated for altruistic purposes are later sold by the recipients.

27. Radin MJ (1987) Market inalienability. Harvard Law Review 100.

28. Arnold R, Bartlett S, Bernat J (2002) Financial incentives for cadaver organ donation: an ethical reappraisal. Transplantation 73(1361).

29. MacKinnon CA (1991) Toward a feminist theory of the state. Cambridge Mass Harvard UP, UK.

30. Wilkinson S (2003) Bodies for sale: Ethics and exploitation in the human body trade. Routledge, London 210-211.

31. Calabresi G (2003) An introduction to legal thought: Four approaches to law and to the allocation of body parts. Stanford Law Review 55(2113) (describing a range of inherent conservatism in traditional formalist thinking).

32. Goodwin M (2004) Altruism's limits: Law, capacity and organ commodification. Rutgers L Rev 56(2): 104. (commenting on the inadequacies of the public or legal method of obtaining body tissues and the problems that stem from private or black-market methods for obtaining body parts).

33. Calabresi G (2003) An introduction to legal thought: Four Approaches to law and to the allocation of body parts. Stan L Rev 55(2113): 2115-2116. 